\title{
The Determinants and Effects of Training at Work: Bringing the Workplace Back in
}

\author{
Philip J. O’Connell and Delma Byrne
}

This article brings together two research fields: work-related training and highperformance work practices (HPWP). We estimate models of both the determinants and the impact of training. Our models of the determinants of training confirm previous research: age, education, contract, tenure, and firm size all influence training. Several components of HPWP are associated with a higher probability of training, specifically general (non-firm-specific) training. Participation in general training is associated with higher earnings, as is involvement in highly participative and consultative working arrangements, and performance reward systems. These patterns of training and returns to training are broadly consistent with HPWP approaches and represent a challenge to human capital theory. We used propensity score matching techniques and Rosenbaum bounds to test for selection in our models of both training and wages.

\section{Introduction}

There has been a resurgence of interest in recent years in the importance of education and training in furthering the goals of economic progress, fuller employment, and social integration. This resurgence of interest in learning coincides with renewed interest in the features of organizations that promote organizational performance and enterprise profitability. These organizational factors include high-performance work practices (HPWP) such as team working, employee involvement, and innovative incentive systems, as well as new technology and labour force flexibility. In general, research has tended to deal with these two important fields of inquiry in a fragmented manner, despite their obvious interconnections in the workplace. This article combines the two perspectives. In examining the determinants of training at work, we look not only at the influence of personal and job characteristics but also at the impact of HPWP and other dimension of change in the workplace. In looking at the impact of training on employee wages, we also examine the impact of high performance working arrangements and examine whether training has a greater impact when it is combined with such innovative working arrangements. In the next section, we outline two theoretical approaches that have important implications for workplace training: human capital and HPWP approaches. In the 'Empirical research on the determinants of training' section, we review the research findings relating to the determinants of training and in the 'Wage effects of training and HPWP' section its effects on wages. The 'Data and findings' section presents our data and findings, and finally, last section presents our conclusions.

\section{Theoretical Framework}

The dominant theoretical framework informing most of the research attempting to understand patterns of 
participation in training has been the human capital approach. This approach, deriving from Becker (1975), situates the training participation decision in a classical utility maximizing framework within competitive labour markets: individual workers undertake training, and employers invest in training, on the basis of their estimates of future returns (including employment prospects and wages for the former and productivity gains for the latter). With regard to training at work, the human capital approach emphasizes the key distinction between 'general' versus 'specific' training. General training is defined in terms of its transferability: general training may be of use to current and subsequent employers, whereas specific training is of use only to the current employer. In this approach, employers will be unlikely to pay for general training. If employers were to pay for general training, they would have to recoup the cost by paying a wage below marginal productivity after training, and in a competitive labour market, the workers would leave to earn their full marginal product with another employer. This gives rise to the poaching problem, whereby 'non-training' employers can pay higher rates to workers who have received general training from a previous employer. This has obvious implications for who bears the cost of training, and a consequence of this market failure is that there is underinvestment in training. Extensions of the theory suggest that employees pay for general training either directly or in the form of lower wages during the training period.

This hypothesis does not receive much support from the empirical literature, which has found: (i) that the theoretical distinction is difficult to operationalize and (ii) that many employers pay for both general and specific training. Most job-related training appears to be general and at least partially paid for by the employer. This is confirmed by findings from Booth and Bryan (2002) in relation to the UK; Pischke (2000) in Germany; and Loewenstein and Spletzer (1999) and Bishop (1994) in the United States. For example, Booth and Bryan (2002) found that about 85 per cent of respondents to the British Household Panel Survey considered their training to be general in nature and 89 per cent reported that it was employer financed. O'Connell (2004) shows that almost 80 per cent of employees in an Irish survey who received employersponsored training considered that the training was general and could be used both in their current job or be of use to another employer. Evertsson's (2004) analysis of an employee survey in Sweden shows that only about 5 per cent of training is regarded as firm specific in Sweden and another 38 per cent is industry- but not firm specific, and over half is general and fully portable across sectors and firms.

A key assumption of the human capital approach is that labour markets are perfectly competitive, which is, of course, an idealized notion. This assumption underpins the idea that employees can capture the full return on the investment in (general) training, either by earning their marginal product with their current employer or by moving to a different employer. Much of the recent literature has challenged this assumption. An important article by Acemoglu and Pischke (1999) argues that compressed wage structures, which may arise due to trade union organization or to collective bargaining at sectoral or national levels, alter the incentive structure and give rise to a situation in which wages of trained workers, relative to untrained, are held down, with the result that employers can capture at least some of the returns to training. Other reasons advanced for why employers may pay for general training also emphasize departures from perfect competition in the labour market, including transaction costs (including asymmetrical information), institutional factors (including trade unions and internal labour markets), and labour market regulation (such as employment protection legislation or minimum wages; Acemoglu and Pischke, 1999, 2003). Much of the empirical literature suggests that institutions are important in moderating the influence of competitive labour markets and thus lowering the barriers to employer sponsorship of training in general, and general training in particular. Loewenstein and Spletzer (1998) develop a model in which training is determined within long-term contracts, including minimum wage guarantees. Bassanini and Brunello (2003), in an analysis of European Community Household Panel Survey (ECHP) data for seven countries, find that the incidence of general training (proxied by off-site training) is higher in sectors with lower differentials between wage growth of trained versus untrained workers. They find no evidence of a relationship between firm-specific training and the training wage premium. Brunello (2001) finds that countries with higher union density, stronger employment protection, and lower minimum wages tend to show higher incidence of training.

The development of the human capital approach led to an emphasis on the competitive labour market, arguably, mainly on the supply side, and to the neglect of processes, institutions, and relationships in the workplace. Rapid developments in the organization and technology of production and service delivery in a context of progressive globalization have led to increased attention to the way work is organized and 
the adoption of HPWP. We use HPWP as a summary term to refer to a collection of innovative systems for the organization of work, including flat hierarchical structures, team working, greater participation of employees in decision making, quality programmes, job rotation, and innovative payment or incentive schemes (see Appelbaum and Blatt, 1994; Mandel and Levine, 2004). The central argument uniting the various strands of the approach is that the adoption of HPWP can benefit employers through enhanced productivity and performance, and at least in some versions, may also benefit their employees through higher wages and greater job satisfaction as well as other subjective measures of welfare. There is little consensus on what constitutes HPWP, and on how to measure their components. Most authors define HPWS or other forms of workplace innovations in terms of combinations of work practices from a list that may include employee involvement or participation in decision making, enhanced communication, team working, quality circles, incentivized reward systems, or flexible working arrangements (see for example Huselid, 1995; Ichniowski et al., 1996).

Firms adopting HPWP are also likely to implement special training measures in order to enhance employees' capacities to implement innovative work practices. Indeed Appelbaum et al. (2000) see training as a core component of HPWP, in addition to the opportunities to participate in decision making and incentive systems that encourage skill acquisition, participation, and employee retention. Similarly, Becker and Gerhardt (1996) argue that HPWP includes training, self-managed teams, incentivized pay, and quality circles, while Kalmi and Kauhanen (2008) employ the first three of these, as well as traditional teams and information sharing in their operationalization of workplace innovations. Whitfield (2000) argues that the introduction of HPWP involves workers taking on a higher level of skill and that many of the new practices require those closely involved in the production process becoming skilled problem solvers, implying that more training is required. Increased flexibility of assignment associated with HPWP also requires a wider range of skills, again, implying heavier reliance on training to implement HPWP.

Not only are HPWP likely to increase the demand for skills and training but also their adoption has implications for the types of training in which employers will be willing to invest. Successful implementation of HPWP requires enhanced capacity of workers directly involved in production and service delivery to perform more complex tasks, or to conduct statistical analysis of quality issues, or to use soft skills such as problem solving or interaction skills in order to facilitate effective team working (Osterman 2006). Most of these skill requirements appear general in nature. Lynch and Black (1998) in their analysis of US employer data, found that employers who had adopted elements of HPWS (total quality management or benchmarking) trained a greater proportion of their workers and that the training was more likely to be general in nature, such as computer training, teamwork training, and basic education. In this respect, HPWP differs sharply from the human capital approach, which expects that employers will not pay for general training. This is not to say that training within a HPWP context is exclusively general. Handel and Levine (2004) argue that new work practices may also require more firm-specific skills.

HPWP represent a context in which innovative work practices are complemented by skill development practices as well as employee retention and security policies (Appelbaum et al., 2000; Godard 2001). To the extent that HPWP entail expectations of enduring employment relationships, employers need to worry less that trained employees will be poached by other employers-a key barrier to training investment identified by the human capital approach - and thus may be more willing to provide both general and firm-specific training.

\section{Empirical Research on the Determinants of Training}

There is a substantial body of evidence indicating that in-career training is highly stratified, with the result that those with higher skills or educational attainment are more likely to participate in training and in training sponsored by their employers (Lynch, 1994; Blundell, Dearden and Meghir, 1996; Schömann, 1998; OECD, 1999; O'Connell, 2002). The employed receive more training than the unemployed, who in turn receive more training than those not economically active (O'Connell, 1999). Older workers are also less likely to participate in job-related training (Gelderblom and de Koning, 2002). Larger firms and those that pay above average wages are also more likely to train their employees (O'Connell, 2002). Part-time workers and those on temporary contracts are less likely to receive training (Arulampalam and Booth, 1998). These patterns of participation suggest that current allocation principles are in inverse relation to need, and training is more likely to exacerbate rather than mitigate existing labour market inequalities. In general, there 
is little evidence to suggest any marked gender differences in access to training. The evidence on gender differences in access to training is mixed (O'Connell, 1999; Evertsson, 2004; Dieckhoff and Steiber, 2010). Participation in training has also been found to decline over the life course. This may be due to the difficulty in recouping the costs of training in either wages or productivity among older workers, given that the time span for cost recovery is shorter among older workers. In the United Kingdom, a great deal of training has been found to be induction training of new recruits (Booth and Bryan, 2002).

Trade unions represent an important labour market institution that may affect training either directly, through training agreements, or indirectly, through wage bargaining. The empirical results on the impact of unions on training are mixed. A number of studies have found a positive impact of union membership or presence on training: for example, in the United States (Lynch, 1992), the United Kingdom (Booth et al., 2003), and Germany (Dustmann and Schönberg, 2004). On the other hand, however, Mincer (1983) and Barron et al. (1987) find negative effects for the United States, and Bassanini et al. (2005) find no significant effect of unions across the 13 countries covered by the ECHP.

There are a limited number of studies examining the impact of HPWP on training. Osterman (1995) in an analysis of firm-level data in the United States shows that new forms of work organization are associated with higher rates of training. He finds that the main influential factors are related to quality practices: quality circles, total quality management, and statistical process control, each of which led to increased training. Other more direct work practices, such as team working and job rotation, did not. His findings also suggest that the adoption of these work practices are short term, but do not endure over time. Osterman (1995) also found that enterprises that responded positively to a question about their commitment to increasing 'the well-being of employees with respect to their personal or family situation' showed higher rates of training. This may be a proxy for progressive employment policies. MacDuffie and Kochan (1995) find that training is positively correlated with the introduction of 'lean production systems' and new work practices in the automobile assembly industry. Whitfield (2000) shows that British workplaces implementing HPWP have higher levels of training. He also shows a strong correlation between the adoption of a comprehensive net of such practices (a bundle) and the amount or intensity of training.
O'Connell (2007) finds that the presence of participatory arrangements for deciding how work is actually carried out is associated with a higher probability of training. Similarly, employees reporting extensive consultation relating to their jobs are also more likely to have received training. These work practices are also associated with an increased likelihood of participation in general rather than firm-specific training. Similarly, Lynch and Black (1998) find that new workplace practices such as total quality management and benchmarking are linked with more general types of training programmes.

\section{Wage Effects of Training and HPWP}

The wealth of empirical research on the labour market effects of initial education (see for example, De la Fuente and Ciccone, 2002) stands in stark contrast to the paucity of research on the effects of continuing vocational training, which can still be characterized as a developing field of inquiry. Most empirical work suggests that there are positive wage returns to training (see Blundell, Dearden and Meghir, 1996 in the United Kingdom; Schömann and Becker, 2002 in Germany; Goux and Maurin, 2000 in France). However, it should be acknowledged that when selection effects are controlled for, the returns are frequently found to be small or even non-significant (see for example, Dieckhoff, Jungblut and O'Connell, 2007).

Brunello (2001) in an analysis of ECHP data for 13 European countries finds that training, both onand off-the-job, increases current earnings growth although this earnings growth is likely to be temporary. Earnings growth is somewhat higher for those with upper secondary education than those with tertiary education, and among the latter, the returns to training decline with labour market experience, perhaps because educational qualifications become outdated over an extensive period of time.

One of the interesting findings from the literature on the impact of training is that the wage returns may be higher among those with low propensity to participate in training (e.g. Bartell, 1995 in the United States; Blundell, Dearden and Meghir, 1996 and Booth, 1991 in the United Kingdom; Pischke, 1996 in Germany). Higher returns to training among groups with low rates of training participation (such as those with low educational attainment) could be due to selection effects, but could also be due to higher returns to training among those with poor qualifications who nevertheless work in the 
primary segment of the labour market, or, in the formulation of Booth and Zoega (2000), in 'good' firms, where the average stock of human capital is high.

Human capital theory assumes a competitive labour market in which trained employees receive their marginal product, and thus the full fruits of their labour enhanced by training. However, in a non-competitive labour market workers may not receive their full marginal product and the benefits of training may be shared between employer and employee. There is some evidence that the benefits of training are shared between employer and employee. Barron et al. (1989) found that the benefits of training are split more or less equally between productivity gains reaped by employers and wage increases to employees in the United States. Dearden et al. (2000) show that the effect of training on productivity was twice as large as that on wages in a panel study of British industries. Other studies that have looked at the impact of training on corporate performance also suggest that employers do appropriate at least some of the returns to training investments (Loewenstein and Spletzer, 1998; Barrett and O'Connell, 2001).

Some of the returns to training are captured by workers either with a time lag or when they change employers. Loewenstein and Spletzer (1999) find that the estimated effect of general training in a previous job is three times higher than in the current job. Booth and Bryan (2002) find that employer-provided training increases wages in both current and future firms and that the impact is larger in future firms. These effects suggest that employers have some monopsony power over their own trained workers so that trained workers may not receive their marginal product and that training, including general training paid for by employers, may be transferable across jobs. These effects are not consistent with the implications of the human capital approach and the assumption of a competitive labour market.

Research on the impact of HPWP is growing and covers the effects on both employers and employees. However, research on the impact of such practices on wages remains somewhat sparse (see Handel and Levine, 2004 for a review). Appelbaum et al. (2000), in their study of the steel, apparel, and medical instruments industries in the United States, show that teamwork and an index of HPWP were associated with higher earnings in steel and apparel, but not in medical instruments. Batt (2001) found that work discretion was positively associated with earnings, but that team and quality circles were not when appropriate controls were included in her model. Cappelli and Neumark (2001) find higher earnings associated with HPWP in a national survey of US manufacturing establishments, but Black, Lynch and Krivelyova (2004) working with the same data find that the positive effects of HPWP are confined to unionized workplaces and to non-production workers, while production workers' wages are not affected. Handel and Gittelman found no evidence of higher wages among employees in firms that had implemented HPWP. Osterman (2000) found no effect of HPWP in his study of a survey of establishments. However, Osterman (2006) found increased wages among blue-collar workers, attributable to increased productivity, as well as increased earnings among managers, achieved through different channels. Forth and Millward (2004) found that employees in high-involvement workplaces earned a wage premium of 8 per cent compared with workers in traditional workplaces. Kalmi and Kauhanen (2009) found that a range of HPWPs, including selfmanaged teams, traditional teams, information sharing, incentivized pay, as well as training, which they regard as an inherent component of HPWP, were all associated with higher wages in a survey of Finnish employees. If training is an inherent element of HPWP arrangements, then we might expect to find that other HPWP have positive effects on training and that if HPWP and training both have positive effects on wages, then the impact of training could be reduced when other components of HPWP are controlled for.

\section{Data and Findings}

This article draws on the Survey of Employees' Attitudes and Experiences of the Workplace conducted by the Economic and Social Research Institute and commissioned by the Irish National Centre for Partnership and Performance (O'Connell et al., 2004). This is a sample survey of 5,200 employees, conducted in mid 2003, designed to collect information relating to characteristics of jobs and workplaces, workplace practices, participation and involvement, experience of and attitudes to change, as well as a series of conventional socio-demographic indicators (age, gender, education, occupation, etc.). The survey also collects information on employer-sponsored training and includes information on whether the training received is general or specific in nature. ${ }^{1}$ In the analyses that follow, binary and multinomial probit models are used to assess the determinants of training. With respect to the methodology used to model the 
impact of training on earnings, we begin with a standard Mincer-type wage model and then include relevant variables. At each step of the analysis, propensity score matching (PSM) and sensitivity tests are carried out in order to test the robustness of our findings (see Aakvik, 2001; DiPrete and Gangl, 2004; Mavromaras, McGuinness and Fok, 2007). Sample means and training rates are shown in Table 1.

\section{Training Patterns}

Overall 48 per cent of employees report that they participated in training provided by their present employer over the last 2 years. The variation in employer-sponsored training shows a familiar pattern. Males are somewhat more likely than females to participate in training. Workers aged 25-39 are most likely to receive training, and training incidence declines substantially among those aged $\geq 55$ years. Training participation is closely linked to educational attainment: only 37 per cent of those with a lower secondary qualification received training, compared with almost 60 per cent of those with third-level qualifications.

There is also variation in training according to job characteristics: full-time workers are more likely to receive training than part-time workers; permanent workers receive more training than those on temporary contracts. Tenure with the current employer is also important with all those who have been in a job for more than a year more likely to receive training than those who have less than a year of job tenure. Union members are substantially more likely to have participated in training than non-members.

In relation to organizational characteristics, training is much more common in the public sector: almost 60 per cent of workers in the public sector compared to 45 per cent of those in the private sector participated in employer-sponsored training in the previous 2 years. There is some variation according to the sector of employment: training incidence is highest in Public Administration and Defense (65\%), followed by Transport and Communications (56\%), while training incidence is lowest in Other Services (40\%) (data not shown). Training is also strongly influenced by establishment size: those working in establishments with 100 or more employees are twice as likely to participate in training as those in establishments with 1-4 employees (63 versus 29\%, respectively). Training incidence is substantially higher among those who are personally involved in participatory work arrangements and those covered by performance reward systems.
Table 1 Sample means and standard deviations (weighted)

Variable Training mean rate

\begin{tabular}{|c|c|c|}
\hline \multicolumn{3}{|l|}{ Training } \\
\hline Any training & 0.48 & 48.2 \\
\hline \multicolumn{3}{|l|}{ Personal characteristics } \\
\hline Female & 0.46 & 46.4 \\
\hline Age & 36.3 & 35.6 \\
\hline Age $(\text { years })^{2}$ & 5.9 & 5.89 \\
\hline Age $25-39$ & 0.40 & 50.6 \\
\hline Age $40-54$ & 0.30 & 46.7 \\
\hline Age $55+$ & 0.08 & 38.4 \\
\hline Lower secondary & 0.16 & 37.1 \\
\hline Upper secondary & 0.51 & 49.9 \\
\hline University & 0.21 & 59.3 \\
\hline Married & 0.54 & 49.9 \\
\hline \multicolumn{3}{|l|}{ Job characteristics } \\
\hline Temporary contract & 0.15 & 37.5 \\
\hline 29 hours or less & 0.18 & 39.3 \\
\hline $\begin{array}{l}<1 \text { year with current } \\
\text { employer }\end{array}$ & 0.16 & 36.8 \\
\hline $\begin{array}{l}1-5 \text { years with current } \\
\text { employer }\end{array}$ & 0.36 & 51.0 \\
\hline Years employed & 8.3 & 8.7 \\
\hline Years employed $^{2}$ & 2.5 & 2.5 \\
\hline Trade union member & 0.38 & 59.2 \\
\hline \multicolumn{3}{|l|}{$\begin{array}{l}\text { Organization structure } \\
\text { and change }\end{array}$} \\
\hline Public sector & 0.19 & 59.5 \\
\hline$<5$ Employees & & 29.4 \\
\hline 5-19 Employees & 0.25 & 43.5 \\
\hline 20-99 Employees & 0.31 & 48.8 \\
\hline 100-500 Employees & 0.30 & 58.0 \\
\hline 500+ Employees & & 63.2 \\
\hline Part of larger organization & 0.70 & 50.8 \\
\hline Reorganization of company & 0.38 & 57.7 \\
\hline New technology introduced & 0.48 & 57.9 \\
\hline New chief executive & 0.25 & 61.9 \\
\hline $\begin{array}{l}\text { Introduction of family } \\
\text { friendly policies }\end{array}$ & 0.25 & 60.6 \\
\hline \multicolumn{3}{|l|}{ HPWP } \\
\hline Participation & 0.26 & 65.8 \\
\hline Consultation & 2.3 & 2.1 \\
\hline $\begin{array}{l}\text { Performance reward } \\
\text { systems }\end{array}$ & 0.12 & 68.3 \\
\hline $\begin{array}{l}\text { Progressive employment } \\
\text { policies }\end{array}$ & 0.76 & 53.6 \\
\hline
\end{tabular}

\section{Modelling the Determinants of Training}

Table 2 presents a series of probit regression models of training incidence, measured as a binary variable, and coded 1 if any employer-sponsored training was 
Table 2 Binary probit regression model of determinants of participation in training

\begin{tabular}{|c|c|c|c|c|c|c|c|c|}
\hline & $\begin{array}{l}\text { Equation } 1 \\
\text { Coefficient }\end{array}$ & $P>z$ & $\begin{array}{l}\text { Equation } 2 \\
\text { Coefficient }\end{array}$ & $P>z$ & $\begin{array}{l}\text { Equation } 3 \\
\text { Coefficient }\end{array}$ & $P>Z$ & $\begin{array}{l}\text { Equation } 4 \\
\text { Coefficient }\end{array}$ & $P>z$ \\
\hline Constant & -3.607 & 0.000 & -1.233 & 0.095 & -0.917 & 0.233 & -0.458 & 0.559 \\
\hline Female & -0.094 & 0.013 & -0.035 & 0.394 & -0.041 & 0.359 & -0.017 & 0.701 \\
\hline Age & -0.091 & 0.000 & -0.026 & 0.206 & -0.006 & 0.770 & 0.001 & 0.955 \\
\hline $\mathrm{Age}^{2}$ & 1.096 & 0.000 & 0.223 & 0.376 & -0.027 & 0.918 & -0.132 & 0.617 \\
\hline Upper secondary education & 0.316 & 0.000 & 0.306 & 0.000 & 0.261 & 0.000 & 0.199 & 0.000 \\
\hline Third-level education & 0.595 & 0.000 & 0.567 & 0.000 & 0.463 & 0.000 & 0.334 & .000 \\
\hline Married & 0.123 & 0.008 & 0.116 & 0.015 & 0.113 & 0.019 & 0.082 & 0.095 \\
\hline Temporary contract & & & -0.131 & 0.027 & -0.154 & 0.012 & -0.097 & 0.117 \\
\hline Part time & & & -0.129 & 0.013 & -0.043 & 0.423 & -0.031 & 0.570 \\
\hline Years employed & & & -0.034 & 0.000 & -0.034 & 0.000 & -0.035 & 0.000 \\
\hline Years employed $^{2}$ & & & 0.242 & 0.000 & 0.219 & 0.000 & 0.225 & 0.000 \\
\hline Union member & & & 0.448 & 0.000 & 0.250 & 0.000 & 0.247 & 0.000 \\
\hline Public sector & & & & & 0.166 & 0.019 & 0.161 & 0.026 \\
\hline 5-10 employees & & & & & 0.242 & 0.000 & 0.220 & 0.001 \\
\hline 11-20 employees & & & & & 0.241 & 0.000 & 0.217 & 0.002 \\
\hline $100+$ employees & & & & & 0.412 & 0.000 & 0.354 & 0.000 \\
\hline Large & & & & & 0.037 & 0.391 & 0.007 & 0.866 \\
\hline Reorganization & & & & & 0.063 & 0.175 & 0.054 & 0.254 \\
\hline New technology & & & & & 0.199 & 0.000 & 0.157 & 0.000 \\
\hline New CEO & & & & & 0.146 & 0.003 & 0.134 & 0.008 \\
\hline Family friendly & & & & & 0.189 & 0.000 & 0.087 & 0.068 \\
\hline Participation & & & & & & & 0.291 & 0.000 \\
\hline Consultation & & & & & & & 0.108 & 0.000 \\
\hline Performance & & & & & & & 0.273 & 0.000 \\
\hline Programme policy & & & & & & & 0.242 & 0.000 \\
\hline$N$ & 4548 & & 4548 & & 4548 & & 4548 & \\
\hline$\chi^{2}$ & $202.75^{\star * *}$ & & $388.78^{\star * *}$ & & $595.2^{* * *}$ & & $748.35^{* * *}$ & \\
\hline Pseudo $R^{2}$ & 0.032 & & 0.0617 & & 0.0944 & & 0.1187 & \\
\hline
\end{tabular}

${ }^{* * *}$ Significant at $1 \%$.

undertaken over the previous 2 years. Equation 1 includes only personal characteristics. The results show that females are less likely than males to have participated in training. Age is also influential, as older workers are less likely to receive training than younger workers. As expected, educational attainment is important: those who have attained upper secondary or university education are more likely to have participated in training than those with lower levels of educational attainment. Employees who are married or living with a partner are also more likely to receive training.

Equation 2 adds job characteristics. In line with our expectations, temporary workers are less likely to have received training than permanent employees, as are part-time workers relative to full-time workers. Also as expected, tenure in the current job has a positive influence on the probability of receiving training. Union members and members of staff associations are also more likely to have trained. The inclusion of job characteristics eliminates the observed gender and age differences in training participation. The effects of education are diminished, but remain significant.

Equation 3 then considers organizational characteristics and change. ${ }^{2}$ Size is important: the larger the organization, the greater the likelihood that an employee has participated in training. In addition, organizational changes in the past 2 years, such as the introduction of substantial new technology, the appointment of a new chief executive or equivalent, or the introduction of family friendly policies, are all associated with an increased likelihood of training. When these organizational characteristics are added to the model, the coefficients for education levels have again diminished, but remain significant.

Equation 4 then adds a series of HPWP, related to the implementation of specific HPWP. There is considerable variation in the literature in how HPWP are operationalized (see for example Addison, 2005). We measure three core dimensions of HPWP: 
participation, voice or consultation, and performance reward systems. Participation is a dichotomous variable scored 1 if employees report that their employer provides them with a direct say in the way in which work is actually carried out (including working in teams, problem-solving groups, quality circles, continuous programmes or groups) and if the employee personally participates in any of these groups. ${ }^{3}$ Consultation is a scale variable, indicating the frequency with which employees are consulted about decisions affecting their work, as well as whether any attention is paid to their views, and thus represents a measure of employee voice (Cronbach's $\alpha=0.84$ ). Performance Reward Systems is measured as a binary variable coded 1 if the respondent is both subject to regular performance reviews and receives performancerelated pay or profit sharing. We include an additional related work practice: Progressive Employment Policies, a binary variable scored 1 if the respondent is employed in a workplace that has either a formal explicit policy on respect and dignity at work and/or if there is a formal explicit policy on equal opportunities in the workplace. Table 2 shows that employees who report that they participate directly in decisions about how work is carried out are more likely to have received training. Similarly, those who report greater levels of consultation are more likely to have received training than those who do not. Employees who participate in performance reward systems are also more likely to receive training as are those workers employed in a workplace that has implemented progressive employment policies.

\section{Distinguishing between General and Specific Training}

One of the key distinctions in the economics of training is that between 'general' versus 'specific' training. General training is defined in terms of its transferability: general training may be of use to both current and subsequent employers, whereas specific training is of use only to the current employer. In the Survey of Employees' Attitudes and Experiences of the Workplace respondents who indicated that they had participated in employer education or training provided by their employer over the past 2 years were asked: ${ }^{4}$

Do you feel that the skills or knowledge which you have acquired in this education or training would be of any use to you in getting a job with another employer or was the education or training specific to your current job only?
Of use in getting job with another employer

$\theta_{1}$

Of use only in current job

$\theta_{2}$

Eighty per cent of all education and training undertaken by employees with employer sponsorship was general in nature, considered by respondents to be 'Of use in getting a job with another employer'. Only about 20 per cent of training was considered to be specific, 'of use only in current job'. This pattern, whereby most training is general in nature, is similar to that found in other countries (see for example, Booth and Bryan, 2002 in the United Kingdom; Pischke, 2000 in Germany; and Loewenstein and Spletzer, 1999 in the United States).

Women are somewhat more likely than men to report that their training was general in nature. Previous analysis of this data set (O'Connell, 2007) shows that older workers are less likely than their younger colleagues to participate in general training and that a somewhat greater proportion of those without any qualifications who received training reported that it was general in nature, compared to those with higher levels of educational attainment. There were no significant differences in the nature of training between full- and part-time workers, or between employees on temporary versus permanent contracts, although as we have seen permanent workers are much more likely to receive training than temporary workers. A substantially greater proportion of training in the public sector is specific to the current employer (31 per cent) than is the case in the private sector (17 per cent). The balance between general versus specific training does not vary much by size of organization.

In order to model the determinants of different types of training, Table 3 reports the results of a multinomial probit estimation, showing participation in either general or specific training contrasted with no training. As expected, overall the patterns differ markedly between the two types of training.

In most respects, the factors that influence participation in any kind of training also influence general training. This is true for educational qualifications, experience, trade union membership, firm size, organizational change (new technology, CEO), and HPWP. This is perhaps not surprising given that about 80 per cent of all training is regarded as general in nature. Employees who report that their organization encourages direct participation in workplace decisions or greater levels of consultation about their work are more likely to have received general training than those who do not. Furthermore, employees who report that their workplace implements 
Table 3 Multinomial probit regression of determinants of general training versus no training and specific training versus no training

\section{General training}

Coefficient Standard error

Constant

Female

Age

Age $^{2}$

Upper secondary education

Third-level education

Married

Temporary contract

Part time

Years employed

Years employed $^{2}$

Union member

Public sector

5-10 employees

11-20 employees

$100+$ employees

Large organization

Reorganization

New technology

New CEO

Family friendly

Participation

Consultation

Performance

Programme policy

$N=4548$

$\chi^{2}=801.91^{* * *}$
Specific training

Coefficient Standard $\quad \boldsymbol{P}>\mathbf{Z}$

error

$\begin{array}{rrrrrr}-1.405 & 1.147 & 0.221 & -0.091 & 1.429 & 0.949 \\ 0.038 & 0.066 & 0.560 & -0.184 & 0.083 & 0.027 \\ -0.011 & 0.031 & 0.727 & 0.039 & 0.039 & 0.314 \\ -0.010 & 0.386 & 0.980 & -0.659 & 0.480 & 0.170 \\ 0.225 & 0.080 & 0.005 & 0.372 & 0.103 & 0.000 \\ 0.462 & 0.084 & 0.000 & 0.385 & 0.108 & 0.000 \\ 0.110 & 0.071 & 0.118 & 0.081 & 0.089 & 0.366 \\ -0.094 & 0.090 & 0.297 & -0.186 & 0.117 & 0.112 \\ -0.100 & 0.080 & 0.209 & 0.101 & 0.099 & 0.305 \\ -0.059 & 0.013 & 0.000 & -0.022 & 0.016 & 0.176 \\ 0.351 & 0.088 & 0.000 & 0.197 & 0.111 & 0.076 \\ 0.298 & 0.071 & 0.000 & 0.410 & 0.090 & 0.000 \\ 0.142 & 0.104 & 0.173 & 0.367 & 0.127 & 0.004 \\ 0.316 & 0.101 & 0.002 & 0.240 & 0.126 & 0.058 \\ 0.371 & 0.101 & 0.000 & 0.076 & 0.127 & 0.549 \\ 0.564 & 0.108 & 0.000 & 0.225 & 0.136 & 0.097 \\ 0.047 & 0.064 & 0.464 & -0.087 & 0.080 & 0.277 \\ 0.057 & 0.068 & 0.401 & 0.102 & 0.084 & 0.226 \\ 0.193 & 0.063 & 0.002 & 0.221 & 0.079 & 0.005 \\ 0.188 & 0.072 & 0.009 & 0.152 & 0.089 & 0.088 \\ 0.164 & 0.068 & 0.016 & 0.006 & 0.085 & 0.941 \\ 0.379 & 0.066 & 0.000 & 0.387 & 0.082 & 0.000 \\ 0.180 & 0.029 & 0.000 & 0.051 & 0.036 & 0.159 \\ 0.436 & 0.093 & 0.000 & 0.088 & 0.124 & 0.478 \\ 0.344 & 0.080 & 0.000 & 0.256 & 0.106 & 0.016\end{array}$

${ }^{* * *}$ Significant at $1 \%$.

performance reward systems or progressive employment policies are more likely to receive general training. These outcomes are entirely consistent with the expectations and findings of previous HPWP research.

When we consider the determinants of specific training, again we find that some of the factors that influence participation in any kind of training also influence specific training: education, trade union membership, organizational change (new technology, CEO), as well as progressive employment policies. Public sector workers and men are more likely to receive specific, but not general, training. The only HPWP to influence specific training is direct participation in the way work is carried out. This suggests that employees' participation in work teams, project groups, or quality circles, etc. may require firm-specific training in order to do so effectively, a finding that is consistent with Handel and Levine (2004).

\section{PSM and Rosenbaum Bounds Sensitivity Analysis}

Concluding from these analyses that employees working with HPWP arrangements are more likely to receive training may not be the whole story because of possible endogeneity. Individuals with a preference for working in a HPWP environment may also have a higher probability of participating in training. For example, individuals with a particular propensity for self-development may be likely to both seek out HPWP arrangements and to participate in training. Failure to control for this potential correlation will yield an estimated HPWP effect on training that is biased. To address this we used PSM and subsequent sensitivity tests to examine the potential effect of both observed and unobserved variables. As a first step, a series of propensity scores was operationalized as the predicted probability of employees engaging in each of the 
HPWP arrangements. ${ }^{5}$ Table 4 provides a summary of diagnostics after PSM and covariate balancing. The matching process created a high degree of covariate balance between the treatment and control samples, as can be seen from the reduction in pseudo $R^{2}$ after matching. There were no systematic differences in the distribution of covariates between treatment and control groups in the equations relating to participation and performance reward systems. For the progressive employment policies and consultation equations, there was some evidence to suggest that

Table 4 Summary of diagnostics after PSM and covariate balancing

\begin{tabular}{|c|c|c|c|}
\hline & Pseudo $R^{2}$ & $L R \chi^{2}$ & $\boldsymbol{P}>\chi^{2}$ \\
\hline \multicolumn{4}{|l|}{ Participation } \\
\hline \multicolumn{4}{|c|}{ Nearest neighbour } \\
\hline Unmatched & 0.158 & 889.03 & 0.000 \\
\hline Matched & 0.006 & 25.16 & 0.799 \\
\hline \multicolumn{4}{|l|}{ Consultation } \\
\hline \multicolumn{4}{|c|}{ Nearest neighbour } \\
\hline Unmatched & 0.102 & 494.96 & 0.000 \\
\hline Matched & 0.019 & 186.62 & 0.000 \\
\hline \multicolumn{4}{|c|}{ Progressive employment policies } \\
\hline \multicolumn{4}{|c|}{ Nearest neighbour } \\
\hline Unmatched & 0.223 & $1,014.14$ & 0.000 \\
\hline Matched & 0.050 & 470.49 & 0.000 \\
\hline \multicolumn{4}{|c|}{ Performance reward systems } \\
\hline \multicolumn{4}{|c|}{ Nearest Neighbour } \\
\hline Unmatched & 0.239 & 806.85 & 0.000 \\
\hline Matched & 0.024 & 36.63 & 0.262 \\
\hline
\end{tabular}

systematic differences hold in the distribution of covariates between the treatment and control groups. However, the pseudo $R^{2}$ dropped substantially before and after matching, indicating that most of the variance has been accounted for. ${ }^{6}$

We then consider the difference in mean outcomes in the matched samples to obtain an estimate of the average treatment effect on the treated, given that PSM removes most of the bias attributable to observable covariates. Table 5 presents the estimates of the unconditional ATT of each of the HPWP based on the nearest-neighbour algorithm and compares these to the marginal effects of the results shown in Table 2. Column 1 of Table 5 gives mean outcomes among treatment cases, while column 2 gives the mean outcomes among all control cases in the sample. The third column shows the mean outcome among the matched controls. The average treatment effect of each HPWP on the treated employees actually receiving the treatment is given in column 4 and can be calculated as the difference between columns 1 and 3. Column 5 shows the marginal effect for the effect of the HPWP on training estimated in Equation 4, Table 3. Column 6 presents the number of treated and control cases in the matched sample.

Table 5 shows that the estimated effect from PSM supports the previous findings from the probit regression: employees engaged in each of the HPWP are more likely to receive training. Compared with the marginal effects derived from the probit regression presented in Table 2, the matching estimates tend to be slightly more conservative (i.e. lower) in the case of participatory work practices, but higher for consultation and performance reward systems.

Table 5 Treatment effects of HPWP on training, matching estimates

$$
\begin{array}{llllll}
Y_{\mathrm{t}} & \text { Raw } Y_{\mathrm{c}} \quad \text { Matched } Y_{\mathrm{c}} & \theta=\Delta \boldsymbol{m} / \mathrm{fx} \quad \text { Treated Control }
\end{array}
$$

\begin{tabular}{|c|c|c|c|c|c|c|c|}
\hline \multicolumn{8}{|l|}{ Participation } \\
\hline Training & 0.656 & 0.443 & 0.557 & 0.099 & 0.116 & 1,409 & 3,117 \\
\hline General training & 0.508 & 0.331 & 0.428 & 0.079 & 0.077 & 1,409 & 3,117 \\
\hline Specific training & 0.147 & 0.101 & 0.128 & 0.019 & 0.026 & 1,409 & 3,117 \\
\hline \multicolumn{8}{|l|}{ Consultation } \\
\hline Training & 0.534 & 0.391 & 0.460 & 0.073 & 0.043 & 3,470 & 1,022 \\
\hline General training & 0.419 & 0.272 & 0.304 & 0.115 & 0.047 & 3,470 & 1,022 \\
\hline \multicolumn{8}{|c|}{ Progressive employment policies } \\
\hline Training & 0.539 & 0.314 & 0.431 & 0.108 & 0.095 & 3,403 & 911 \\
\hline General training & 0.415 & 0.244 & 0.325 & 0.089 & 0.082 & 3,403 & 911 \\
\hline \multicolumn{8}{|c|}{ Performance reward systems } \\
\hline Training & 0.663 & 0.479 & 0.531 & 0.132 & 0.108 & 552 & 3,968 \\
\hline General training & 0.570 & 0.360 & 0.416 & 0.153 & 0.126 & 552 & 3,968 \\
\hline
\end{tabular}


In order to estimate the extent to which selection on unobservables may bias our inferences, we conducted a Rosenbaum bounds sensitivity analysis. Table 6 reports the results of the $P$-values from Mantel-Haenszel tests for the average treatment effect on the treated while setting the level of hidden bias to a certain value $r$. At each $r$, a hypothetical significance level ' $P$-critical' is derived which represents the bound on the significance level of the treatment effect in the case of endogenous selection into treatment status. Table 6 reports the Rosenbaum bounds on treatment effects when $r=1$, which in the model implies no unobserved selection bias. It also reports the $r$ value at which we would have to question our conclusion of a positive effect, meaning that a confounding variable could have an equally strong effect on both treatment and outcome. We see that robustness to hidden bias is rather similar across each of the HPWP. The PSM test combined with the sensitivity analysis suggests that the estimates presented are unaffected by biases that may arise from unobserved heterogeneity.

\section{Wage Effects of Training and HPWP}

We now turn to the results from the analyses of earnings, measured here as the log of hourly net pay for each individual employee. Because net earnings are used, it is important to include marital status in the wage equation because of Irish tax law, which despite elements of individualization of the tax code, nevertheless provides substantial tax breaks for married couples. The mean hourly earnings for our sample as a whole are $€ 11.75$ (weighted). For those who received training in the past 2 years, hourly earnings are $€ 12.61$, compared with $€ 10.96$ for those who did not receive training. This simple comparison strongly suggests higher earnings for those who have received training relative to those who have not. We conduct regression analysis to see if the earnings difference remains when we control for the variety of factors that influence earnings other than participation in training. We estimate standard ordinary least squares (OLS) Mincer-type wage equations in which the standard controls are included. In Table 7, we include a dummy variable indicating if an employee has received training in the past 2 years, and in Table 8 we include two dummy variables measuring, respectively, whether an employee has received general training or specific training.

Equation 1 in Table 7 includes just personal characteristics. Those who have received training in the past 2 years are paid about 10 per cent higher more than those who have not. Females earn 15 per cent less than males, older workers earn more than younger workers, and those with higher levels of education earn more than those with lower levels of educational attainment. Those who are married or living with a partner earn more than those who are not married.

Equation 2 adds job characteristics and this reduces the coefficient on training to 7 per cent, and the effects of personal characteristics also fall somewhat. As expected, workers on temporary contracts earn less than those on permanent contracts. Part-time workers earn higher hourly wages than full-time employees; trade union/staff association members earn higher wages than non-members.

Equation 3 adds variables pertaining to organizational characteristics and change, and the return to training falls to 5 per cent. The patterns outlined above in relation to personal and job characteristics remain largely stable. In relation to the new variables added to the model, those working in the public sector earn about 7 per cent more than those working in the private sector. Those working in larger organizations earn more than those in smaller organizations. Furthermore, employees working in companies that are part of a larger organization earn higher wages. Work organization changes are not significantly related

Table 6 Summary of Rosenbaum bounds for HPWP treatment effects

\begin{tabular}{|c|c|c|c|c|c|}
\hline & $r$ & $Q-m h^{+}$ & Q_m $\boldsymbol{h}^{-}$ & p_m $m h^{+}$ & p_mh $\mathbf{m}^{-}$ \\
\hline \multirow[t]{2}{*}{ Participation } & 1.00 & 06.40 & 06.40 & 0.000 & 0.000 \\
\hline & 1.55 & 1.39 & 11.5 & 0.817 & 0.000 \\
\hline \multirow[t]{2}{*}{ Consultation } & 1.00 & 06.83 & 06.83 & 0.000 & 0.000 \\
\hline & 1.55 & 1.35 & 12.49 & 0.088 & 0.000 \\
\hline \multirow[t]{2}{*}{ Performance reward systems } & 1.00 & 4.527 & 4.527 & 0.000 & 0.000 \\
\hline & 1.55 & 1.483 & 7.639 & 0.069 & 0.000 \\
\hline \multirow[t]{2}{*}{ Progressive employment policies } & 1.00 & 8.85 & 8.85 & 0.000 & 0.000 \\
\hline & 1.95 & 1.37 & 16.94 & 0.0850 & 0.000 \\
\hline
\end{tabular}




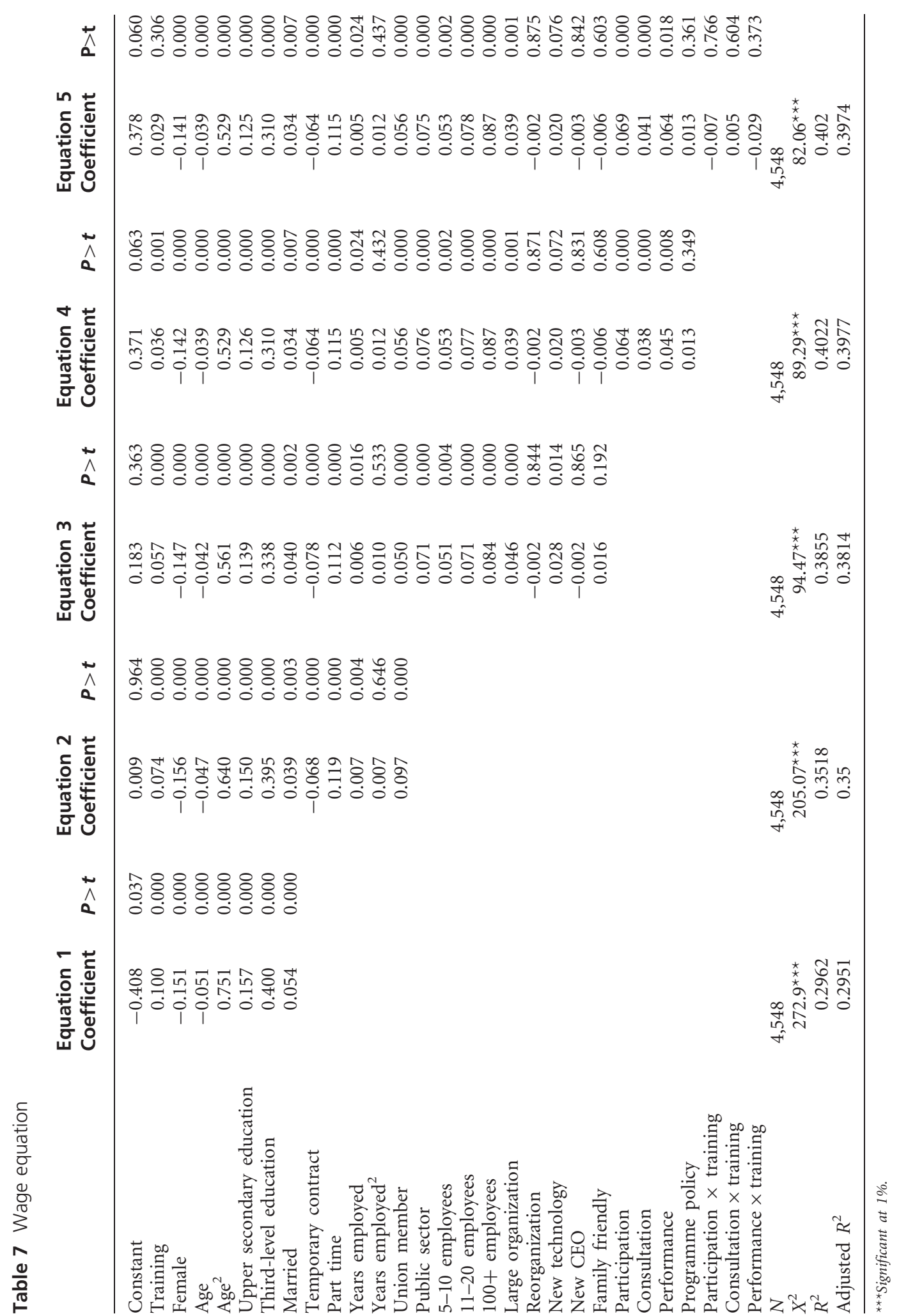


a

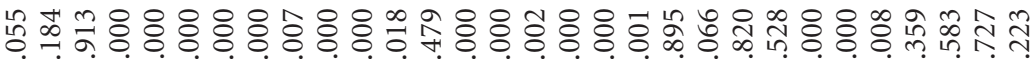

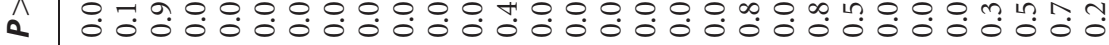

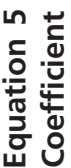

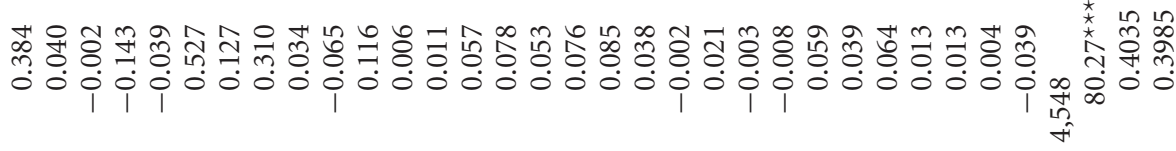

ז

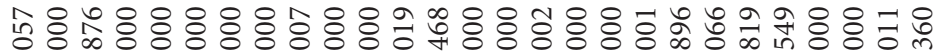

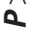

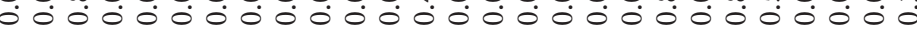

竞

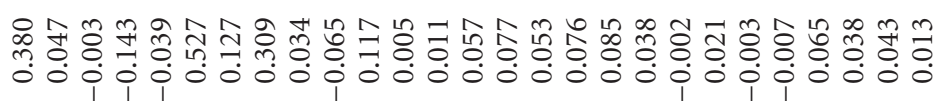

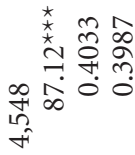

$\hat{\Lambda}$

iᄋ m

$\hat{\alpha}$

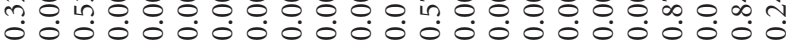

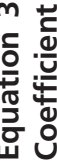

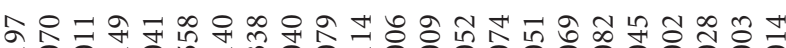

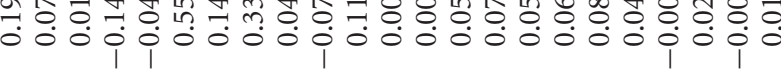

$\ddot{\wedge}$

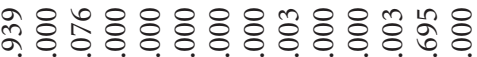

a

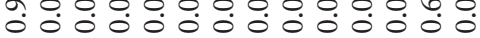

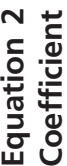

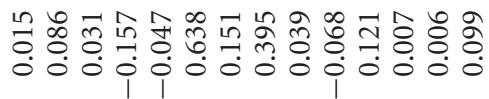

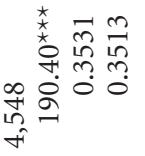

ז

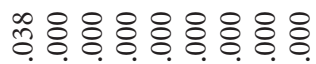

a

c.

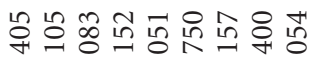

坴苏药

i.

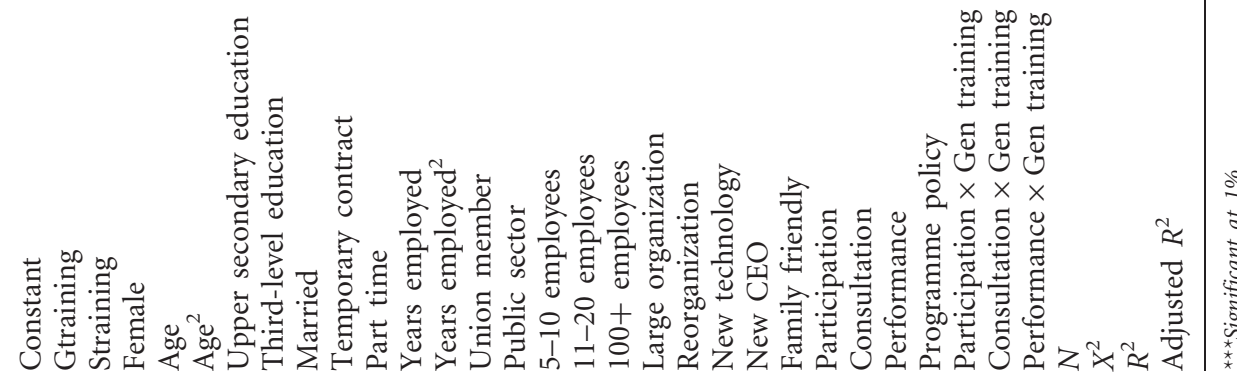


to wages, but the introduction of new technology does increase wages.

Equation 4 then includes HPWP. Employees who report that they participate directly in deciding how work is carried out earn higher wages, as do employees who are involved in performance reward systems. The strength of consultation about work is also positively related to wages. However, the presence of progressive employment policies in the workplace does not have any significant impact on wages, suggesting that that there is no necessary correlation between well paid work and progressive employment policies, and also that employers do not use such policies as substitutes for wages. The addition of the HPWP variables reduces the return to training to just less than 4 per cent.

Finally, equation 5 examines whether training has a greater impact when combined with HPWP by specifying interaction terms between training and each of participation, consultation, and performance reward systems. None of the interaction terms reach significance suggesting that the effect of training on wages does not differ significantly across work practices, and that the impact of training does not increase when it is combined or 'bundled' with HPWPs, as hypothesized in some accounts (Ichniowsky et al., 1996; Appelbaum et al., 2000).

\section{Returns to General/Specific Training}

Table 8 considers the returns to general and specific training. Equation 1 presents the results in relation to personal characteristics. Here the return to general training is higher than the return to specific training; 10 per cent compared with 8 per cent, respectively. When job characteristics are added, in Equation 2, the return to specific training is eliminated, but those who received general training in the past 2 years earn almost 9 per cent more than those who did not. With the addition of organizational characteristics in Equation 3, the return to general training falls to 7 per cent, and the inclusion of work practices in Equation 4 further reduces the return to general training to just under 5 per cent. As in Table 7, above, before, none of the interactions between general training and HPWP-participation, consultation, or performance reward systems-achieved statistical significance suggesting that the effect of general training on wages does not vary across work practices.

As before, the OLS estimates do not account for the endogenous decision to participate in training. Individuals who receive training may be substantially different to those not receiving training either in terms of observed or unobserved characteristics, and thus standard regression estimation methods may produce biased estimates of the effect of training on wages. As before, this potential difficulty can be rectified using PSM estimators and inferences can then be checked by conducting sensitivity tests.

Table 9 shows that the estimated effects from PSM support our findings of positive effects of training on wages. Both the matching estimate and the OLS estimate suggest that overall training is associated with a 4 per cent wage premium, and general training with a return of the order of 5-6 per cent. In order to estimate the extent to which selection on unobservable variables may bias our inference about the effect of training on wages, Table 10 reports the results from a Rosenbaum bounds sensitivity test. As before, the bounds allow us to assess the extent to which an unobserved variable must influence the selection process in order to render the matching estimates unreliable. The finding of a positive effect of training overall is less robust to the presence of hidden bias than the effect of general training. In respect of the latter, the critical level of $r$ at which we would have to question our conclusion of a positive effect of general training is $1.2-$ it is attained if an unobserved covariate was to cause the odds ratio of training versus no training to differ by a factor of about 1.2. However, it should be noted that these results are worst-case scenarios (see DiPrete and Gangl, 2004). Furthermore, Aakvik (2001) argues that while the sensitivity test shows how biases might alter inferences, it does not indicate whether biases are present or what magnitudes are plausible. Hence, we conclude that a value for $r$ of 1.2 does not mean that there is no true positive effect of general training on wages. Rather, it can be interpreted as conveying information about the level of uncertainty contained in matching estimators by showing just how large the influence of a confounding variable must be to undermine the

Table 9 Treatment effects of training on wages, matching estimates

$$
\begin{aligned}
& N \quad Y_{\mathbf{t}} \text { Raw Matched } \theta=\Delta Y \text { OLS } \\
& Y_{c} \quad Y_{c}
\end{aligned}
$$

$\begin{array}{lrlllll}\text { Training } & & & & & \\ \text { Treated } & 2275 & 2.53 & 2.35 & 2.49 & 0.038^{*} & 0.036 \\ \text { Control } & 2255 & & & & & \\ \text { General training } & & & & & \\ \text { Treated } & 1751 & 2.53 & 2.35 & 2.47 & 0.056^{*} & 0.047 \\ \text { Control } & 2255 & & & & & \end{array}$

${ }^{*}$ Significant at $5 \%$. 
Table 10 Summary of Rosenbaum bounds for training treatment effects

\begin{tabular}{lcrrrrrr} 
& Gamma & Sig $^{+}$ & Sig $^{-}$ & t-hat $^{+}$ & t-hat $^{-}$ & Cl $^{+}$ & Cl$^{-}$ \\
\hline Training & 1.00 & $<0.001$ & $<0.001$ & 0.036 & 0.036 & 0.013 & 0.059 \\
General training & 1.1 & 0.124 & $<0.001$ & 0.013 & 0.059 & -0.009 & 0.082 \\
& 1.00 & $<.001$ & $<0.001$ & 0.060 & 0.060 & 0.033 & 0.086 \\
& 1.2 & 0.123 & $<0.001$ & 0.015 & 0.105 & -0.011 & 0.131 \\
\hline
\end{tabular}

conclusion of the matching analysis. Moreover, it should be noted in this respect that none of the observed covariates specified in the training model (Equation 4 in Table 3) achieved such influence over the probability of participating in general training. Therefore, using this approach we can conclude that the estimated returns to general training are likely to be robust with respect to possible selection bias, although there is greater uncertainly in respect of training overall (combining both general and specific training). Furthermore, using this approach ensures that levels of estimation bias are greatly reduced by comparing the outcomes of individuals in the treatment and control groups who hold very similar characteristics in terms of individual, job, and work practice characteristics.

\section{Conclusions}

This article started from the premise that the workplace is an important site for the accumulation of human capital. Our approach, therefore, has been to bring together two research fields: the large and relatively sophisticated training literature with the growing literature on workplace practices. Our findings suggest that workplaces are indeed important.

We estimate models of both the determinants and the impact of training. Our model of training participation confirms much of the existing literature: age, education, type of contract, tenure, and firm size are all determinants of training. We also found that several work practices are also influential: involvement in highly participative or consultative working arrangements; as well as the existence of performance reward systems and progressive employment policies are all associated with a higher probability of training. When we distinguish between general and firm-specific training, we find that several types of HPWP lead to greater levels of general training. This is consistent with the implication of the HPWP literature and represents a challenge to the human capital approach which has difficulty explaining why employers would pay for general training.

To assess the impact of training, we estimate a series of wage models. Simple models, controlling for personal and job characteristics, show training to have a significant impact on wages. The addition of variables measuring organizational characteristics confirms that organizational factors are important influences on wages, and their inclusion also reduces the estimated returns to training. We also find that several dimensions of HPWP, particularly participation, consultation, and performance reward systems, have a significant impact on wages, and when these variables are specified in the model, training continues to show a modest, smaller, return. These returns are confined to general training: we find no significant returns to firm-specific training.

We have shown that individuals who are involved in highly participative and consultative working arrangements, and in organizations that implement performance reward systems, are more likely to train, and to earn more, than those who are not. To assess whether training has a greater impact when combined with these HPWP, we specify a series of interaction terms between training and HPWP, but found no evidence of a wage return to such 'bundles' of practices.

The literature on the returns to training acknowledges that individuals who receive training may be substantially different to those not receiving training either in terms of individual or workplace characteristics (including HPWP), and thus standard regression estimation methods may produce biased estimates of the effect of training on wages. We apply a PSM technique to ensure that our models of both the determinants and returns to training are robust with respect to possible selection bias.

We believe that the contribution of this article is to suggest that future attempts to rigorously estimate the impact of training on wages should take account of the workplace and the social relations within it. Our findings suggest that observed patterns of training and returns to training are broadly consistent with the 
implications of the HPWP approach and represent a challenge to elements of the human capital approach.

\section{Notes}

1. The survey we used does not collect information on whether the training is conducted on-the-job or off-the-job. While the survey also collects information on the duration of training, the data are of poor quality, with a highly skewed distribution, and we decided that it was not of sufficient quality to support analysis.

2. In this and all subsequent analyses, models that include organizational characteristics also include sectoral dummy variables that are not shown in the tables because of space considerations. In the present analysis, we found that construction and health workers are more likely to have trained than those in manufacturing, and those working in hospitality are less likely.

3. Working in teams is included as a measure of participation. Given the constraints of the data, further investigation was not possible in relation to different types of teamwork and the effect these may have on employee outcomes.

4. We would argue that asking those directly involved in the training and focusing on its transferability represents a useful approach to capturing the Becker distinction between general and specific training.

5. The independent variables include all variables that were entered in the analyses of Table 2, with the exception of the HPWP that formed the dependent variable.

6. Throughout the PSM matching, we use a number of different matching algorithms to match treatment and control cases with similar propensity scores, but the results from the nearest neighbour are presented here as they provide the most conservative results. Results for the other algorithms are available from the authors.

\section{Acknowledgements}

This article was prepared with partial funding from the EqualSoc Network of Excellence funded by the European Union's Sixth Framework Programme. We wish to thank our colleagues in the
EMPLOY-EDUC research group on The Training Gap in Lifelong Learning for comments on earlier drafts of the article.

\section{Funding}

This research was carried out as part of a research project 'The Training Gap in Lifelong Learning' under the EQUALSOC Network of Excellence, funded under the EU 7th Framework Programme. The survey to collect the data used in this paper was commissioned and funded by the Irish National Centre for Partnership and Performance.

\section{References}

Aakvik, A. (2001). Bounding a matching estimator: the case of a Norwegian training program. Oxford Bulletin of Economics and Statistics, 63, 115-143.

Acemoglu, D. and Pischke, J. S. (1999). Beyond Becker: training in imperfect labour markets. The Economic Journal, 109, F112-F142.

Acemoglu, D. and Pischke, J. S. (2003). Minimum wages and on-the-job training. In Polachek, S. and Tatsiramos, K. (Eds.), Research in Labor Economics. Vol. 22, pp. 159-202.

Addison, J. T. (2005). The Determinants of Firm Performance: Unions, Works Councils, and Employee Involvement/High Performance Work Practices. IZA Discussion Paper No. 1620.

Appelbaum, E. et al. (2000). Manufacturing Advantage: Why High Performance Work Systems Pay Off. Ithaca, NY: ILR Press.

Appelbaum, E. and Blatt, R. (1994). The New American Workplace. Ithaca: NY: ILR Press.

Arulampalam, W. and Booth, A. L. (1998). Training and labour market Flexibility: is there a trade-off? British Journal of Industrial Relations, 36, 521-536.

Barrett, A. and O'Connell, P. J. (2001). Does training generally work? The returns to in-company training. Industrial and Labour Relations Review, 54, 647-662.

Bartell, A. (1995). Training, wage growth, and job performance: evidence from a company database. Journal of Labor Economics, 3, 401-425.

Bassanini, A. and Brunello, G. (2003). Is Training More Frequent When Wage compression is Higher? Evidence from the European Community Household Panel. IZA Discussion Paper No. 839, August.

Bassanini, A. et al. (2005). Workplace Training in Europe. IZA Discussion Paper 1640, Institute for the Study of Labor (IZA). 
Batt, R. (2001). Explaining wage inequality in telecommunications services: customer segmentation, human resource practices, and union decline. Industrial and Labor Relations Review, 54, 425-449.

Becker, G. (1975). Human Capital, 2nd edn. New York: Columbia University.

Becker, S. O. and Caliendo, M. (2007). mhboundsSensitivity Analysis for Average Treatment Effects. IZA Discussion Paper Series No. 2542.

Becker, S. and Inchino, A. (2002). STATA programmes for ATT estimation based on propensity score matching. The STATA Journal, 2, 358-377.

Bishop, J. (1994). The Impact of previous training on productivity and wages. In Lynch, L. (Ed.), Training and the Private Sector. Chicago, IL: University of Chicago Press.

Black, S., Lynch, L. and Krivelyova, K. (2004). How workers fare when employers innovate. Industrial Relations, 43, 44-66.

Blundell, R., Dearden, L. and Meghir, C. (1996). The Determinants and Effects of Work-related in Britain. London: Institute for Fiscal Studies.

Booth, A. (1991). Job-related formal training: who receives it and what is it worth? Oxford Bulletin of Economics and Statistics, 53, 281-294.

Booth, A. and Bryan, M. (2002). Who Pays for General Training? New Evidence for British Men and Women. IZA Discussion Paper No. 486.

Booth, A. and Zoega, G. (2000). Why Do Firms Invest in General Training? 'Good' Firms and 'Bad' Firms as a Source of Monopsony Power. CEPR Discussion Paper No. 2536.

Brunello, G. (2001). On the Complementarity between Education and Training in Europe. IZA Discussion Paper Series, No. 309, Bonn: Institute for the Study of Labour.

Cappelli, D. and Neumark, D. (2001). Do high performance work practices improve establishment-level outcomes? Industrial and Labor Relations Review, 54, 735-737.

Dieckhoff, M., Jungblut, J.-M. and O'Connell, P. (2007). Job-related training in Europe: do institutions matter? In Gallie, D. (Ed.), Employment Regimes and the Quality of Work. Oxford: Oxford University Press.

Dieckhoff, M. and Steiber, N. (2010). A re-assessment of common theoretical approaches to explain gender differences in continuing training participation. British Journal of Industrial Relations. doi:10.1111/j.1467-8543.2010.00824.x [Epub ahead of print 16 November 2010].
DiPrete, T. A. and Gangl, M. (2004). Assessing bias in the estimation of casual effects: Rosenbaum bounds on matching estimators and instrumental variables estimation with imperfect instruments. Sociological Methodology, 34, 271-310.

Dustmann, C. and Schönberg, U. (2004). Training and Union Wages. IZA Discussion Paper No. 1435.

Evertsson, M. (2004). Formal on-the-job training: a gender-typed experience and wage-related advantage? European Sociological Review, 20, 79-94.

Forth, J. and Millward, N. (2004). High involvement managers and pay in Britain. Industrial Relations, 43, 98-119.

Gelderblom, A. and de Koning, J. (2002). Exclusion of older workers, productivity and training. In Schömann, K. and O'Connell, P. J. (Eds.), Education, Training and Employment Dynamics. Cheltenham, UK: Edward Elgar.

Goux, D. and Maurin, E. (2000). Returns to firm-provided training: evidence from French worker-firm matched data. Labour Economics, 7, $1-19$.

Handel, M. and Levine, D. (2004). Editors' introduction: the effects of new work practices on workers. Industrial Relations: A Journal of Economy and Society, 43, 1-43.

Huselid, M. (1995). The impact of human resource management practices on turnover, productivity, and corporate financial performance. Academy of Management Journal, 38, 635-672.

Ichniowski, C., Kochan, T., Levin, D. and Olsen, C. (1996). What works at work? Overview and assessment. Industrial Relations, 35, 299-333.

Kalmi, P. and Kauhanen, A. (2008). Workplace innovations and Employee outcomes: evidence from Finland. Industrial Relations, 47, 430-459.

Loewenstein, M. and Spletzer, J. (1999). General and specific training: evidence and implications. Journal of Human Resources, 34, 710-733.

Lynch, L. (Ed.), (1994). Training and the Private Sector: International Comparisons. Chicago, IL: University of Chicago Press.

Lynch, L. M. (1992). Private-sector training and the earnings of young workers. American Economic Review, 82, 299-312.

Lynch, L. M. and Black, S. E. (1998). Beyond the incidence of training: evidence from a national employers' survey. Industrial and Labor Relations Review, 52, 64-81.

Mavromaras, K., McGuinness, S. and Fok, Y. K. (2007). Assessing the Incidence and Wage Effects of Over-Skilling in the Australian Labour Market. IZA Discussion Paper No. 2837. 
O'Connell, P. J. (1999). Adults in Training: An International Comparison of Continuing Education and Training. OECD Center for Educational Research and Innovation, WD(99)1. Paris: OECD.

O'Connell, P. J. (2002). Does enterprise-sponsored training aggravate or alleviate existing inequalities? Evidence from Ireland. In Schömann, K. and O'Connell, P. J. (Eds.), Education, Training and Employment Dynamics. Cheltenham, UK: Edward Elgar, pp. 285-302.

O'Connell, P. J. (2007). Who generally trains? The effects of personal and workplace characteristics on training at work. In Lassnigg, L. et al. (Eds.), Lifelong Learning: Building Bridges through Transitional Labour Markets. Apeldoorn, Belgium: Het Spinhuis.

O'Connell, P. J., Russell, H., Williams, J. and Blackwell, S. (2004). The Changing Workplace: A Survey of Employees' Views and Experience. Dublin, Ireland: The National Centre for Partnership and Performance and the Economic and Social Research Institute.

OECD, (Ed.), (1999). Training of adult workers in OECD countries: measurement and analysis. In OECD (1999). Employment Outlook. Chapter 3, Paris: OECD, pp. 135-175.

Osterman, P. (1995). Skill, training, and work organization in American establishments. Industrial Relations: A Journal of Economy and Society, 34, 125-146.
Osterman, P. (2006). The wage effects of high performance organization in manufacturing. Industrial and Labour Relations Review, 59, 187-204.

Pischke, J. S. (1996). Continuous Training in Germany. National Bureau of Economic Research, Working Paper No. 5829.

Rosenbaum, P. R. (2002). Observational Studies, 2nd edn. New York: Springer.

Schömann, K. and O'Connell, P. (Eds.), (2003). Education, Training and Employment Dynamics. Cheltenham: Edward Elgar.

Whitfield, K. (2000). High performance workplaces, training, and the distribution of skills. Industrial Relations, 39, 1-25.

\section{Authors' Addresses}

Philip O'Connell (to whom correspondence should be addressed), The Economic and Social Research Institute, Whitaker Square, Sir John Rogerson's Quay, Dublin 2, Ireland.

Email: philip.oconnell@esri.ie

Delma Byrne, Department of Sociology, National University of Ireland Maynooth (NUIM), Maynooth, Co. Kildare, Ireland.

Email: delma.byrne@nuim.ie

Manuscript received: July 2009 